\title{
AN ASSESSMENT OF MORPHOLOGY AND YIELD CHARACTERISTICS OF PUMPKIN (CUCURBITA MOSCHATA) GENOTYPES IN NORTHERN BANGLADESH
}

\author{
KU Ahamed*, B Akhter, MR Islam, N Ara and MR Humauan \\ Regional Agricultural Research Station, Bangladesh Agricultural Research Institute, Ishurdi, Pabna, \\ Bangladesh
}

Accepted: 06 October 2011

\begin{abstract}
Twenty pumpkin (Cucurbita moschata) genotypes were characterized for morphological and yield attributes in northern area of Bangladesh during kharif season of 2006. The range of first flowering was at 52.0-73.7 days. The early flowering and early maturity was observed in BD-227 genotype. The range of variability was distinct for vine length at harvest, leaf length, leaf diameter, number of branches per plant. The vine length was maximum $(400 \mathrm{~cm})$ in $B D-242$ and minimum $(169 \mathrm{~cm})$ in $B D-$ 255. Leaf length ranged from $30.6-47.2 \mathrm{~cm}$ in different genotypes and the number of branches per plant varied from 2.0-4.7. The number of branches per plant was maximum (4.7) in BD-270. Entry BD-268 produced maximum number of fruits (15.7) per plant and the minimum (2.0) was in BD-251. The maximum average fruit weight $(4.2 \mathrm{~kg})$ was in BD-250 and minimum $(1.5 \mathrm{~kg})$ in BD-257. There was significant variation with regards to yield of different pumpkin genotypes, which was varied from 5.9 $36.0 \mathrm{~kg}$. Among the twenty one pumpkin germplasm, the maximum fruit yield $(36.1 \mathrm{~kg} / \mathrm{plant})$ was recorded in BD-243 genotype which was closely related to BD-234 genotype $(31.1 \mathrm{~kg} / \mathrm{plant})$ and minimum $(5.9 \mathrm{~kg} / \mathrm{plant})$ was in BD-270. The qualitative characteristics of these pumpkin genotypes showed also variation in fruit colour and flesh colour. The over all performance among the genotypes, BD-243, BD-268, BD-242, BD-234, BD-288, BD-250 and BD-227 may be utilized in breeding program.
\end{abstract}

Key words: Assessment; Pumpkin; Morphological and Qualitative characteristics, Northern Bangladesh

\section{INTRODUCTION}

Pumpkin (Cucurbita moschata: Cucurbitaceae) is a very popular vegetable in many tropical and subtropical countries. In Bangladesh it ranks next to brinjal and radish in area under cultivation $(9,600 \mathrm{ha})$ and production $(38,500 \mathrm{t} / \mathrm{annum})$ (BBS, 2009). It is very nutritious due to high content of vitamin A and can play a vital role in meeting the vegetable shortage and nutritional problem. There is a no recommended variety of pumpkin in Bangladesh. Naik (1949) reported that there was a high varietal variations due to cross pollination. Pumpkins are very versatile in their uses for cooking and have an advantage over other vegetables as the fruit can be stored for up to 6 months before being consumed and hence can play an important role in maintaining nutritional levels during the long dry seasons (Mendlinger et al. 1991).

The fruit is typically orange or yellow and have many creases running from the stem to the bottom. They have a thick shell on the outside, with seeds and pulp on the inside. Pumpkins are monoecious, the female flower is distinguished by the small ovary at the base of the petals. These bright and colorful flowers have extremely short life and may only open for as short a time as one day. The color of pumpkins is derived from the orange pigments abundant in them. The main nutrients are lutein and both alpha and beta carotene, the latter of which generates vitamin $\mathrm{A}$ in the body.

In Bangladesh many pumpkin genotypes having diverse characteristics are grown in different parts of the country. Genotypes available in the market do not have uniformity or standardization in nomenclature. Moreover, no information on morphological and agronomical characteristics is available which can be used as delineating and standardizing different accessions. Therefore, the study was undertaken to characterize pumpkin germplasm collection.

\section{MATERIALS AND METHODS}

The investigation was carried out at the Regional Plant Genetic Resources Center, RARS, Ishurdi, Pabna during the Kharif season of 2006. The experiment was laid out in Randomized Complete Block Design with three replications. The unit plot size was $2 \mathrm{~m} \times 1.5 \mathrm{~m}$. The seeds were sown on March 28, 2006. Twenty accessions and one

*Corresponding author : kuahamed70@yahoo.com 
Ishurdi local pumpkin genotype were used for evaluation (Table 1). Seeds of pumpkin germplasm and check variety were sown with $60 \mathrm{~cm} \times 40 \mathrm{~cm}$ spacing. The soil was clay loam in texture. The land was fertilized with cow dung, Urea, TSP, MP and Gypsum@6 ton/ha., 130kg/ha, 135kg/ha, $150 \mathrm{~kg} / \mathrm{ha}$ and Gypsum $100 \mathrm{~kg} / \mathrm{ha}$, respectively. The entire quantity of cowdung, TSP, MP, gypsum and half of urea were applied as basal dose during final land preparation (15 days before sowing) and remaining $50 \%$ of urea was applied at 30 days after sowing. Fungicide, insecticide and other intercultural operations were done when it necessary.

Data were recorded according to IBPGR descriptors lists. Fruits were harvested when half of the fruits turned into mature and data on yield contributing characteristics were recorded on number of fruit per plant, fruit circumference, average fruit weight and yield per plant. Data on inflorescence parameters were recorded on days to $50 \%$ flowering, days to maturity and flower color. Morphological parameters of quantitative data were recorded on vine length at harvest, leaf length, leaf diameter and number of branches per plant and qualitative characteristics were recorded on fruit color, flesh color and fruit shape. The data were statistically analyzed and treatment means were separated by Duncan's Multiple Range Test (DMRT) according to Gomez and Gomez (1984).

\section{RESULTS AND DISCUSSION}

Days to 50\% flowering: Significant variation among the genotypes was observed for this trait (Table 1). The maximum number of days to $50 \%$ flowering determined to be 73days. It was observed that earliest flower opening in the genotype BD227 (52 days). Mendligner et al. (1992) also reported that he evaluated some of the collected pumpkin accessions and days to flowering ranged from 57.3 to 88.3 days

Days to maturity: The genotypes differed significantly for harvest maturity of fruit (Table 1) which ranged from 104 to 123 days. The accession BD 227 recorded the shortest maturity duration while BD 270 had the longest maturity.

Vine length at harvest: The plant height varied from 169.6 to $400.1 \mathrm{~cm}$ (Table 2). The tallest plant $(400.1 \mathrm{~cm})$ was recorded in BD-242 which was followed by BD-234 $(392.9 \mathrm{~cm})$ and $271(382.2 \mathrm{~cm})$. $\mathrm{Ng}$ (1993) also reported that Luffa acutangula is an angled loofah which commonly grown in hot, humid tropical areas in Asia. Plants are generally grown on a trellis. They generally grow up to $0.6 \mathrm{~m}$ in length. Vine growth on the trailing types
Table 1. Performance of inflorescence characteristics of twenty one pumpkin germplasm

\begin{tabular}{lll}
\hline Entries & $\begin{array}{c}\text { Days to } \\
\text { flowering }\end{array}$ & Days to maturity \\
\hline BD-227 & $52.0 \mathrm{i}$ & $104.0 \mathrm{f}$ \\
BD-278 & $55.0 \mathrm{~h}$ & $104.0 \mathrm{f}$ \\
BD-271 & $57.0 \mathrm{~g}$ & $104.0 \mathrm{f}$ \\
BD-270 & $57.7 \mathrm{~g}$ & $123.0 \mathrm{a}$ \\
BD-268 & $64.0 \mathrm{~cd}$ & $104.0 \mathrm{f}$ \\
BD-255 & $55.0 \mathrm{~h}$ & $104.0 \mathrm{f}$ \\
BD-269 & $66.0 \mathrm{~b}$ & $107.0 \mathrm{de}$ \\
BD-257 & $52.7 \mathrm{i}$ & $107.0 \mathrm{de}$ \\
BD-250 & $64.0 \mathrm{~cd}$ & $113.0 \mathrm{~b}$ \\
BD-243 & $63.0 \mathrm{def}$ & $108.0 \mathrm{~cd}$ \\
BD-288 & $62.0 \mathrm{ef}$ & $104.0 \mathrm{f}$ \\
BD-229 & $64.0 \mathrm{~cd}$ & $105.0 \mathrm{ef}$ \\
BD-242 & $61.7 \mathrm{f}$ & $104.0 \mathrm{f}$ \\
BD-282 & $63.7 \mathrm{cde}$ & $110.0 \mathrm{c}$ \\
BD-251 & $63.7 \mathrm{cde}$ & $104.0 \mathrm{f}$ \\
BD-237 & $62.0 \mathrm{ef}$ & $115.0 \mathrm{~b}$ \\
BD-241 & $65.0 \mathrm{bc}$ & $115.0 \mathrm{~b}$ \\
BD-239 & $63.7 \mathrm{cde}$ & $108.7 \mathrm{~cd}$ \\
BD-234 & $61.7 \mathrm{f}$ & $104.0 \mathrm{f}$ \\
BD-235 & $62.7 \mathrm{def}$ & $107.0 \mathrm{de}$ \\
Local & $73.7 \mathrm{a}$ & $108.0 \mathrm{~cd}$ \\
Mean & 62.38 & 107.75 \\
LSD value & 1.890 & 2.343 \\
CV $(\%)$ & $1.84 \mathrm{~d}$ & $1.32 \mathrm{f}$ \\
Range & $52.0-73.7$ & $104.0-123.0$ \\
\hline Fig & & \\
\hline
\end{tabular}

Figures in a column with the same letter (s) do not differ significantly at $5 \%$ level of probability.

pumpkin can be very vigorous with stem lengths totally over $140 \mathrm{ft}$ in some instances.

Leaf Length: BD-270 had the highest leaf length $(47.2 \mathrm{~cm})$ and the lowest leaf length $(30.7 \mathrm{~cm})$ was recorded from BD-288 (Table 2). Mendligner et al. (1992) also reported that some pumpkin accessions the leaf length ranged $3.2-5.3 \mathrm{~cm}$. Cucurbita moschata leaves have petioles of $30 \mathrm{~cm}$ reported by Lira (1991). Grubben and Ngwerume (2004) also reported that leaf length per plant of Cucurbita moschata were 9-24cm long.

Leaf diameter: The genotypes differed significantly for leaf diameter (Table 2) which ranged from 23.7 to $15.3 \mathrm{~cm}$. The highest leaf diameter $(23 \mathrm{~cm})$ was recorded in BD-270 followed by BD-271 $(22 \mathrm{~cm})$. The lowest leaf diameter $15 \mathrm{~cm}$ observed in BD-242. Ng (1993) also reported that $C$. trigonus leaves were $2.5-5 \mathrm{~cm}$ in diameter, $C$. melo leaves were $7.5 \mathrm{~cm}$ diameter and $C$. sativus leaves were $7.5-12.7 \mathrm{~cm}$ diameter. Grubben and $\mathrm{Ng}$ (2004) also reported that leaf diameter per plant of C. moschata were $20-35 \mathrm{~cm}$ in diameter.

Number of branches per plant: Significant variations were observed among the genotypes in 
respect to the number of branches per plant (Table 2). It ranged from 2.02 (in BD-257) to 4.7 (in BD270). Grubben and Ngwerume (2004) also reported that the number of branches per plant of $C$. moschata were 3 - 4 .

Yield characters: The fruit weight of pumpkin genotype BD-250 (4.2 kg) were the heaviest closely followed by BD-234 (3.9 kg). Accession BD-257 $(1.5 \mathrm{~kg})$ produced the smallest fruits. Grubben and Ngwerume (2004) reported that in the varieties studied fruit weight varied widely from $1-10 \mathrm{~kg}$.

Significant variations were observed among the accessions in seed characteristics for dry weight of 100 -seed ranged from 6.4 to $13.6 \mathrm{~g}$.Significant variation was found in yield and yield contributing characteristics (Table 3). The highest number of fruits per plant (15.7) was obtained from BD-268 while the lowest from BD-251 (2.0). Labrada et al. (1997) also reported that among the 34 landraces, 25 were able to produce more than 4-5 fruits per plant. The highest circumstances per fruit $(77.1 \mathrm{~cm})$ was obtained from BD-227 the lowest $(46.3 \mathrm{~cm})$ from BD-257.

Table 2. Average performance of quantitative characteristics of twenty one pumpkin germplasm

\begin{tabular}{|c|c|c|c|c|}
\hline Entries & $\begin{array}{l}\text { Vine length } \\
\text { at harvest } \\
(\mathrm{cm})\end{array}$ & $\begin{array}{l}\text { Leaf } \\
\text { length } \\
(\mathrm{cm})\end{array}$ & $\begin{array}{c}\text { Leaf } \\
\text { Diameter } \\
(\mathrm{cm})\end{array}$ & $\begin{array}{l}\text { No. of } \\
\text { Branch } \\
\text { es/plant }\end{array}$ \\
\hline BD-227 & $235.0 \mathrm{~h}$ & 36.0 ghi & $21.7 \mathrm{~b}$ & $3.0 \mathrm{c}$ \\
\hline BD-278 & $195.1 \mathrm{i}$ & $37.0 \mathrm{fgh}$ & $20.3 \mathrm{~d}$ & $4.0 \mathrm{~b}$ \\
\hline BD-271 & $382.2 \mathrm{a}$ & $42.2 \mathrm{~cd}$ & $22.0 \mathrm{~b}$ & $4.0 \mathrm{~b}$ \\
\hline BD-270 & $310.8 \mathrm{de}$ & $47.2 \mathrm{a}$ & $23.7 \mathrm{a}$ & $4.7 \mathrm{a}$ \\
\hline BD-268 & $340.3 \mathrm{c}$ & $38.3 \mathrm{efg}$ & $19.3 \mathrm{f}$ & $4.0 \mathrm{~b}$ \\
\hline BD-255 & $169.6 \mathrm{i}$ & $33.2 \mathrm{jkl}$ & $18.0 \mathrm{~h}$ & $3.0 \mathrm{c}$ \\
\hline BD-269 & 300.5 ef & $32.0 \mathrm{klm}$ & $21.1 \mathrm{c}$ & $4.0 \mathrm{~b}$ \\
\hline BD-257 & $353.3 \mathrm{bc}$ & $34.2 \mathrm{ijk}$ & $19.0 \mathrm{~g}$ & $2.3 \mathrm{de}$ \\
\hline BD-250 & $260.2 \mathrm{gh}$ & $40.2 \mathrm{de}$ & $21.9 \mathrm{~b}$ & $3.0 \mathrm{c}$ \\
\hline BD-243 & $341.5 \mathrm{c}$ & $45.0 \mathrm{ab}$ & $17.3 \mathrm{i}$ & $3.0 \mathrm{c}$ \\
\hline BD-288 & $278.0 \mathrm{fg}$ & $30.6 \mathrm{~m}$ & $16.9 \mathrm{j}$ & $3.0 \mathrm{c}$ \\
\hline BD-229 & $245.8 \mathrm{~h}$ & $31.2 \mathrm{~lm}$ & $17.1 \mathrm{ij}$ & $2.0 \mathrm{e}$ \\
\hline BD-242 & $400.1 \mathrm{a}$ & $35.6 \mathrm{hij}$ & $15.3 \mathrm{k}$ & $3.0 \mathrm{c}$ \\
\hline BD-282 & $274.7 \mathrm{fg}$ & $43.0 \mathrm{bc}$ & $21.7 \mathrm{~b}$ & $3.0 \mathrm{c}$ \\
\hline BD-251 & $254.9 \mathrm{gh}$ & $33.2 \mathrm{jkl}$ & $17.8 \mathrm{~h}$ & $3.7 \mathrm{~b}$ \\
\hline BD-237 & $330.6 \mathrm{~cd}$ & 39.0 ef & $20.9 \mathrm{c}$ & $3.0 \mathrm{c}$ \\
\hline BD-241 & $381.9 \mathrm{ab}$ & $33.7 \mathrm{ijk}$ & $19.7 \mathrm{e}$ & $4.0 \mathrm{~b}$ \\
\hline BD-239 & $240.8 \mathrm{~h}$ & 34.7 hij & 19.7 e & $3.0 \mathrm{c}$ \\
\hline BD-234 & $392.9 \mathrm{a}$ & $39.5 \mathrm{e}$ & $20.2 \mathrm{~d}$ & $4.0 \mathrm{~b}$ \\
\hline BD-235 & 301.4 ef & $35.0 \mathrm{hij}$ & $17.2 \mathrm{i}$ & $2.7 \mathrm{~cd}$ \\
\hline Local & $335.9 \mathrm{~cd}$ & $34.4 \mathrm{ij}$ & $20.2 \mathrm{~d}$ & $4.0 \mathrm{~b}$ \\
\hline Mean & 301.21 & 36.95 & 19.60 & 3.35 \\
\hline LSD value & 28.65 & 2.44 & 0.33 & 0.42 \\
\hline CV (\%) & 5.76 & 3.98 & 1.05 & 7.66 \\
\hline \multirow[t]{2}{*}{ Range } & 169.6- & $30.7-$ & $15.3-$ & $2.0-4.7$ \\
\hline & 400.1 & 47.2 & 23.7 & \\
\hline
\end{tabular}

The figures in column with the same letter (s) do not differ significantly at $5 \%$ level of probability.
The genotypes showed significant differences for fruit yield per plant (Table 3). The highest yield per plant was recorded in BD-243 $(36.0 \mathrm{~kg})$ followed by BD-234 $(31.1 \mathrm{~kg})$, BD-242 $(28.9 \mathrm{~kg})$, BD-227 $(28.0 \mathrm{~kg})$ and BD-288 (27.0kg) produced statistically similar yield per plant. Among the genotypes, BD-270 had the lowest yield per plant $(5.9 \mathrm{~kg})$ which was statistically identical to the genotypes BD-282 $(5.9 \mathrm{~kg})$, BD-255 $(6.7 \mathrm{~kg})$ and BD-251 (7.4kg). Precheur et al. (2009) also reported that thirty two cultivars $(21$ medium and large size, 8 small and novelty types and 3 minipumpkins) were evaluated at the AVRDC Western branch in South Charleston, OH, USA The top 5 varieties in terms of average fruit size were: Phatso $\mathrm{Jr}$ (13.6kg/fruit), Mustang PMR (13.6kg/fruit), Phatso II (12.3kg /fruit), Gold Medal (11.8 kg/fruit) and Solid Gold (11.4kg/ fruit). Thirteen of the twenty-one varieties tested had an average fruit size of $9 \mathrm{~kg}$ per fruit or greater. Yield for the largest 5 varieties ranged from $49.40 \mathrm{t} / \mathrm{ha}$ for Phatso II to $37 \mathrm{t} / \mathrm{ha}$ for Solid Gold. Only Super Herc, Gladiator, Magic Wand, RPX 1626 and ACX 7302 had yield lower than $37 \mathrm{t} / \mathrm{ha}$

Pumpkin cultivars require 4-6 months frost free time for production. In this study the farmers reported that landraces "Nzunzu" and "Ditimanga" require early planting possibly indicating that they are long season. Landraces "Dasana", "Ndodo" and "Hokore" can be planted in late summer suggesting that they could be shorter season crops.

In Southern Africa, pumpkin production is from seed from landraces that have been maintained by farmers over long periods of time (Gwanama et al. 2000, Chigwe and Saka 1994). They reported that some names were coined from the leaf and fruit color eg. "Nzunzu", some from their fruit size (Ditimanga).

Qualitative characteristics of fruits: The flowers of all accessions were yellow (Table 4). The fruit color ranged from green yellow to brown and the flesh color ranged from whitish to greenish; and orange and deep orange. The fruit shape ranged from elliptical to round and pyriform. Labrada et al. (1997) also reported that among the 34 landraces, the predominant fruit types were the pyriform and crookneck type. Elongate, globular and flat shapes were rare. 
Table 3: Quantitative characteristics of fruits of different pumpkin germplasm (quantitative)

\begin{tabular}{|c|c|c|c|c|c|}
\hline Entries & $\begin{array}{l}\text { Number of fruit/ } \\
\text { plant }\end{array}$ & Fruit circumference $(\mathrm{cm})$ & $\begin{array}{l}\text { Average fruit weight } \\
(\mathrm{kg})\end{array}$ & $\begin{array}{l}\text { Dry weight of } 100- \\
\text { seed }\end{array}$ & $\begin{array}{c}\text { Yield/ } \\
\text { Plant } \\
(\mathrm{kg})\end{array}$ \\
\hline BD-227 & 7.7 ef & $77.1 \mathrm{a}$ & $3.7 \mathrm{abc}$ & $10.8 \mathrm{bcdef}$ & $28.0 \mathrm{abc}$ \\
\hline BD-278 & $3.7 \mathrm{jk}$ & $63.3 \mathrm{cdef}$ & $2.6 \mathrm{efgh}$ & $13.6 \mathrm{a}$ & 9.3 fghi \\
\hline BD-271 & $4.0 \mathrm{ij}$ & $63.3 \mathrm{cdef}$ & $2.8 \mathrm{defg}$ & $12.2 \mathrm{abc}$ & 11.4 fghi \\
\hline BD-270 & $2.7 \mathrm{kl}$ & 56.0 hij & 2.3 efghi & $9.4 \mathrm{fg}$ & $5.9 \mathrm{i}$ \\
\hline BD-268 & $15.7 \mathrm{a}$ & $53.0 \mathrm{j}$ & $1.6 \mathrm{ij}$ & $6.4 \mathrm{i}$ & $24.5 \mathrm{bcd}$ \\
\hline BD-255 & $2.7 \mathrm{kl}$ & $67.8 \mathrm{bc}$ & $2.6 \mathrm{efg}$ & 7.4hi & $6.7 \mathrm{i}$ \\
\hline $\begin{array}{l}\text { BD-269 } \\
\text { BD-257 }\end{array}$ & $\begin{array}{l}6.7 \mathrm{fg} \\
11.0 \mathrm{~cd}\end{array}$ & $\begin{array}{l}60.3 \text { efghi } \\
46.3 \mathrm{k}\end{array}$ & $\begin{array}{l}2.3 \text { efghij } \\
1.5 \mathrm{j}\end{array}$ & $\begin{array}{l}8.3 \mathrm{gh} \\
9.5 \mathrm{fg}\end{array}$ & $\begin{array}{l}\text { 15.2 efgh } \\
17.1 \text { defg }\end{array}$ \\
\hline BD-250 & $5.7 \mathrm{gh}$ & $66.4 \mathrm{bcd}$ & $4.2 \mathrm{a}$ & $10.4 \mathrm{cdef}$ & $23.5 \mathrm{bcd}$ \\
\hline BD-243 & $12.0 \mathrm{bc}$ & $70.6 \mathrm{~b}$ & $2.9 \mathrm{cdef}$ & $11.5 \mathrm{bcde}$ & $36.0 \mathrm{a}$ \\
\hline BD-288 & $10.7 \mathrm{~d}$ & 65.7 bcde & 2.5 efgh & $11.2 \mathrm{bcdef}$ & $27.0 \mathrm{bc}$ \\
\hline BD-229 & $4.7 \mathrm{hij}$ & 60.2 efghi & 2.4 efghi & $10.4 \mathrm{cdef}$ & 10.4 fghi \\
\hline BD-242 & $13.0 \mathrm{~b}$ & 57.4 ghij & 2.2 fghij & $9.8 \mathrm{efg}$ & $28.9 \mathrm{ab}$ \\
\hline BD-282 & $2.7 \mathrm{kl}$ & $63.0 \mathrm{cdef}$ & 2.5 efgh & 9.9efg & $5.9 \mathrm{i}$ \\
\hline BD-251 & 2.01 & $76.7 \mathrm{a}$ & $3.6 \mathrm{abcd}$ & 12.1abcd & 7.4 hi \\
\hline BD-237 & $7.0 \mathrm{ef}$ & 62.4 cdefg & $2.8 \mathrm{defg}$ & $8.3 \mathrm{gh}$ & $20.7 \mathrm{cde}$ \\
\hline BD-241 & $5.0 \mathrm{hi}$ & 57.8 fghij & 2.1 ghij & $9.4 \mathrm{fg}$ & 10.8 fghi \\
\hline BD-239 & $5.7 \mathrm{gh}$ & 62.9 cdefg & 3.1 bcde & $12.5 \mathrm{ab}$ & $17.4 \mathrm{def}$ \\
\hline BD-234 & $8.0 \mathrm{e}$ & 62.6 cdefg & $3.9 \mathrm{ab}$ & $10.3 \mathrm{def}$ & $31.1 \mathrm{ab}$ \\
\hline BD-235 & $5.0 \mathrm{hi}$ & $54.8 \mathrm{ij}$ & $1.8 \mathrm{hij}$ & $9.4 \mathrm{fg}$ & $9.0 \mathrm{ghi}$ \\
\hline Local & $4.0 \mathrm{ij}$ & 60.7 defgh & $2.8 \mathrm{efg}$ & 10.8 bcdef & 11.1 fghi \\
\hline Mean & 6.64 & 62.32 & 2.69 & 10.171 & 17.0 \\
\hline LSD value & 1.160 & 5.801 & 0.8084 & 1.871 & 8.149 \\
\hline CV (\%) & 10.60 & 5.64 & 18.21 & 11.15 & 2.43 \\
\hline Range & $2.0-15.7$ & $46.3-77.1$ & $1.5-4.2$ & $13.6-6.4$ & $5.9-36.0$ \\
\hline
\end{tabular}

The figures in column with the same letter (s) do not differ significantly at $5 \%$ level of probability.

Table 4. Fruit characteristics of different pumpkin germplasm (qualitative)

\begin{tabular}{|c|c|c|c|}
\hline $\begin{array}{l}\text { No. of } \\
\text { accessions }\end{array}$ & $\begin{array}{l}\text { Fruit skin } \\
\text { color }\end{array}$ & Flesh color & Fruit shape \\
\hline BD-227 & Green & Deep Orange & Broad elliptical \\
\hline BD-278 & Green & orange-yellow & Pyriform \\
\hline BD-271 & yellow & Orange & Elliptical \\
\hline BD-270 & Brown & orange-yellow & Round \\
\hline BD-268 & Green & white & Flattened \\
\hline BD-255 & Brown & Deep Orange & Round \\
\hline BD-269 & Yellow & Orange & Oblong \\
\hline BD-257 & Brown & pale green & Round \\
\hline BD-250 & Green & Orange & Broad elliptical \\
\hline BD-243 & Brown & yellow & Broad elliptical \\
\hline BD-288 & Yellow & Deep Orange & Elliptical \\
\hline BD-229 & Brown & pale green & Elliptical \\
\hline BD-242 & Green & Deep Orange & Oblong \\
\hline BD-282 & Brown & yellow & Pyriform \\
\hline BD-251 & Yellow & yellow & Broad elliptical \\
\hline BD-237 & Brown & Deep Orange & Pyriform \\
\hline BD-241 & Green & Orange & Round \\
\hline BD-239 & Yellow & Deep Orange & Broad elliptical \\
\hline BD-234 & Yellow & Orange & Broad elliptical \\
\hline BD-235 & Yellow & yellow & Pyriform \\
\hline Local & Green & Deep Orange & Pyriform \\
\hline
\end{tabular}

\section{CONCLUSION}

Twenty pumpkin (Cucurbita moschata) accession from Bangladesh were characterized for morphological and yield attributes. The range of first flowering was 52-73 days. The early flowering and early maturity was observed in BD227 genotype. The range of variability was distinct for vine length at harvest, leaf length, leaf diameter, number of branches per plant. BD-268 produced the maximum number of 15.7 fruits/ plant. The maximum fruit weight recorded in BD$250(4.2 \mathrm{~kg})$. The maximum fruit yield of $36 \mathrm{~kg}$ recorded in BD-243. The qualitative characteristics of these pumpkin genotypes showed also variation in fruit color and flesh color.

\section{REFERENCES}

BBS (Bangladesh Bureau of Statistics) 2009 Year Book of Agricultural Statistics in Bangladesh. Ministry of planning, Government of Peoples 
Republic of Bangladesh, Dhaka.

Chigwe CFB, Saka VW 1994 Collection and Characterization of Malawi Pumpkin Germplasm. Zim. J. Agric. Res. 32(2): 139149.

Gomez KA and Gomez AA 1984 Statistical Procedure for Agricultural Research. 2nd ed., Intl. Rice Res. Inst., John Willy and Sons, New York, chichester, Brisbane, Toronto, Singapore. PP. 187-240

Grubben GJH and Ngwerume FC 2004 Cucurbita moschata Duchesne In: Grubben, G.J.H. \& Denton, O.A. (Editors). PROTA 2: Vegetables/Légumes. [CD-Rom]. PROTA, Wageningen, Netherlands.

Gwanama C, Labuschagne MT, Botha AM 2000 Analysis of genetic variation in Cucurbita moschata by random amplified polymorphic DNA (RAPD) markers. Euphytica 113: 1924.

Labrada HR, Almirall AF and de la Carrera OB 1997 Cuban Pumpkin Genetic Variability under Low Input Conditions.Cucurbit Genetics Cooperative Report 20:48-49 (article 21) 1997

Lee J 1994. Cultivation of grafted vegetables. I. Current status, grafting methods, and benefits. HortScience 29:235-239.

Lira R 1991 Estudios taxonómico y ecogeográfico de las Cucurbitáceas de Latinoamérica. 3rd biannual report (Jan.-Aug. 1991). Rome, IBPGR.
Lucas EO 1988 The potential of leaf vegetables in Nigeria. Outlook Agr. 17:163-168.

Zhang $X$ and Jiang Y 1990 Edible seed watermelons (Citrullus lanatus (Thunb.) Matsum \& Nakai) in northwest China. Cucurbit Genet. Coop. Rpt. 13:40-42.

Mendlinger S, Chweya J, Benzioni A, Seme A, Ventura M, Lungaho C and Okoko V 1991 Collection, evaluation and breeding of African edible vegetables. BGUN- ARI-25-92. Annual report 1991 on AID-CDR programme.

Mendlinger S, Chweya J, Benzioni A, Seme A, Ventura M, Lungaho C and Okoko V. 1992. Collections, evaluations and breeding of African edible vegetables. BGUN- ARI-25-92. Annual report. AID-CDR programme, BeerSheva, Israel.

Naik KC 1949 South Indian Fruits and their culture.P.Varadachary \& Co., Madras. Martin and Ruberte, 1978

$\mathrm{Ng}$ TJ 1993 New opportunities in the Cucurbitaceae. p. 538-546. In: J. Janick and J.E. Simon (eds.), New crops. Wiley, New York.

Precheur B, Jasinski J, Riedel M, Rhodes L and Pack R 2009 Pumpkin Cultivar Evaluation in Ohio. Dept. of Horticulture and Crop Science, Southwest Extension IPM, Department of Plant Pathology, The Ohio State University, Columbus, OH 43210. 